the E. W. Fairchild-Martinclale Library and Computing Center.

\section{Univ. of Wyoming Libraries benefit from class gift}

The graduating class of 1946 raised $\$ 20,000$ as a 50 th year class reunion gift for the University of Wyoming Libraries (UW). Francois (Margaret) Dickman, a 1946 alumna, orchestrated the fund drive, with its success announced at a Homecoming reunion luncheon on October 11, and again at the football game the next day. The gift will purchase "best books" not already in the libraries collections. The University Libraries sponsor the 50th year reunion luncheon each year at Homecoming.

"This has become a special tradition at UW," said Keith Cottam, director of libraries. "Alums from the class of ' 47 have already stated their intent to double that amount next year, and you can bet we are encouraging the spirit of competition."

\section{Wyoming Consortium receives award}

The Wyoming Academic Libraries Consortium (WALC) received the Wyoming Library Association's 1996 Georgia Shovlain Award for the state's best library project. WALC's Wyoming Academic Libraries Resource Project upgraded telecommunications lines and implemented an Ariel network linking Wyoming's academic libraries and the state library. The network is now expanding to include public libraries.

"The project is helping to overcome some of the geographical and technological remoteness and information isolation in Wyoming,"

\title{
38th RBMS preconference examines history of the book
}

ACRL's Rare Books and Manuscripts Section (RBMS) will hold its 38 th annual preconference at the Claremont Colleges in southern California, June 24-27, 1997. Entitled "Rereading the Past: New Methodologies and Approaches to the History of the Book," the preconference will look at how research in the history of the book has developed since RBMS first looked at the subject in 1980 . No longer the sole purview of the bibliographer and the scholar-librarian, the field has expanded in ways that many rare book librarians may not yet realize. Scholars from many disciplines have entered the field and have given new meaning and purpose to the subject of the history of the book, changing the way we will view the "Book Age."

How does this new scholarship affect rare book and manuscript librarians and curators? And how will it influence collection development, programming, cataloging, teaching, and scholarly research? The RBMS 1997 preconference program will look at the new history of the book, hear some of its most innovative scholars, examine ways in which librarians can take advantage of this burgeoning field for their own use and development, and discuss ways of servicing this interest.

Scheduled speakers will include Robert Gross (College of William and Mary), Jeffrey
Groves (Harvey Mudd College), Rosalind Remer (Moravian College), Steve Ferguson (Princeton University), and Ellen Dunlap (American Antiquarian Society). In addition, there will be a series of shor paper presentations on research in the history of the book primarily by members of RBMS. The preconference will also include a variety of seminars organized by the Seminars Committee of RBMS. Workshops on cataloging and preservation are planned. One day will be spent at the Huntington Library, which will include tours of the grounds and galleries.

Registration is $\$ 175$ for RBMS members, $\$ 210$ for nonmembers. Late registration, after May 15 , will be $\$ 225$ for members and $\$ 265$ for nonmembers. Additional fees will be charged for workshops. Housing and some meals are not included in the registration fee. Housing will be available in residence halls on the Claremont Colleges campuses as well as local motels and hotels. Claremont is located east of Los Angeles, and is a 20-minute drive from the Ontario, California, airport.

Registration material will be available after March 1, 1997. For more information please contact ACRL, 50 East Huron St., Chicago, IL 60611-2795; (800) 545-2433, ext. 2511 or see the RBMS Wel, site at URL: http://www. princeton.edu/ ferguson/rbms.html. 